\title{
Planting pattern of oilseed rape (Brassica napus L.) in intercropping systems - A review
}

\author{
Jagmohan Kaur \\ Department of Agronomy, Punjab Agricultural University, Ludhiana-141004 (Punjab), \\ India \\ E-mail: kaurjagmohan@pau.edu
}

\begin{abstract}
Since per capita availability of land is shrinking day by day and there is little scope for horizontal growth of oilseed rape (Brassica napus L.) and thus vertical growth via intercropping can be a viable alternative to reduce the wide gap between the demand and supply of edible oils. Intercropping is an intensive land use system and a profitable venture especially for the small land holders as it fulfills the diversified demands at the farm level itself. Suitable planting pattern for greater light interception and transmission throughout the crop profile is pre-requisite for getting higher productivity. This paper reviews the information regarding role of planting patterns of oilseed rape on various aspects like growth, yield, competitiveness as well as productivity and profitability of intercropping systems. Different oilseed rape cultivars when intercropped with different crops viz., cereals, legumes, fodders or other oilseed crops prove to be more productive and remunerative as compared to their monoculture at different row proportions or spacings, which also varies with locations.
\end{abstract}

Keywords: Aggressivity, Economics, Gobhi sarson, LER, Oilseed rape, Plant geometry, Row ratio

\section{INTRODUCTION}

In food grains production, India has achieved remarkable strides, but to satisfy the demands of burgeoning population, huge imports of edible oils is a matter of great concern. Rapeseed and mustard is very important class of edible oilseed crops. Globally, India stands third in production of rapeseed and mustard after China and Canada and second in area after China, with a contribution of about 12.5 per cent in the total rapeseed-mustard production (Kumar, 2014). These occupied an area of 5.98 million hectares with production of 8.43 million tonnes and productivity of $1.41 \mathrm{t} \mathrm{ha}^{-1}$ during 2017-18 with per capita availability of $17.7 \mathrm{~kg}$ (Anonymous, 2020). The strategy to enhance production is either to increase the land area under production or to increase productivity per unit area of available land (Aziz et al., 2015). Per capita availability of land is shrinking day by day due to the increasing demand of food grains, urbanization, industrialization and other infrastructural needs imposed by the population pressure, so, there is limited scope for further expansion of area under oilseeds. Thus, the gap between demand and supply of edible oils in the country can be bridged only by increasing their production per unit area per unit time. Therefore, there is very little scope for horizontal growth of the crop. Thus, vertical growth of the crop i.e. intercropping with other crops can be a viable option to increase production of oilseed rape.

Intercropping is an advanced agro technique (Naeem et al., 2013; Aziz et al., 2015), which helps in improving the agronomic output and economic efficiency of the intercropping system as compared to the monoculture via judicious use of available resources in complementary and supplementary manner (Reddy and Suresh, 2008; Khan et al., 2012). It increases the stability of production system by introducing diversity in cropping systems and by lowering crop failure risks. So, intercropping in modern day agriculture is of immense importance for the farmers as it increases productivity of small farms along with satisfying the diversified demands.

Oilseed rape is an important high yielding oilseed crop grown under assured irrigation conditions in fertile soils. It is grown in winter season unlike most of the other oilseed crops and thus lacks competition imposed by other oilseed crops (Uzun et al., 2012). In oilseed rape, initial stage of vegetative growth is slow as compared to the rapid growth in reproductive phase and secondly it requires wider row spacing, resulting in an ample 
scope for intercropping compatible and noncompetitive crops during the initial stages for getting higher productivity. It can be successfully intercropped with different crops viz., wheat, chickpea, lentil, potato, sugarcane, etc. under different agro-climatic regions of India (Singh et al., 2010). Among the various agronomic factors limiting yield, planting pattern is considered to be of great importance. Planting pattern plays an important role to make the intercropping system, a potentially viable and productive system, through the effective use of solar energy, better nutrient utilization and moisture extraction. The optimum row spacing in an ideal intercropping system reduces competition for growth resources, decreases the shading effect of one crop over the other and ensures proper utilization of solar radiation by component crops (Narwal and Kadian, 1991).

Therefore, increase in yield can be ensured by maintaining appropriate plant population through different planting patterns. Diepenbrock (2000) also reported that plant density in rapeseed governs its yield components and ultimately the yield of individual plants and thus a uniform distribution of plants per unit area is a pre-requisite for yield stability. An attempt has been made in this paper to review the effect of planting pattern of oilseed rape (Brassica napus L.) in intercropping systems under different sub-heads.

Growth: Several workers have reported successful intercropping of oilseed rape with different crops viz., wheat (Das et al.,1992; Ali et al., 2000; Khan et al., 2012; Naeem et al., 2013), potato (Rathi and Keim, 1982; Singh and Rathi, 1984; Narwal and Parkash, 1989; Narwal and Kadian, 1991; Narwal and Parkash, 1992), toria (Gupta and Saini, 1986; Chaudhary and Singh, 1993), pea (Mankotia et al., 1994), oats (Singh, 2013; Jamwal, 2002), safflower (Rafey and Prasad, 1991) etc. Arrangement of component crops in different row proportions and spacings leads to maximum light exposure, facilitates inter cultivation and efficient utilization of land and other resources for higher output in terms of yield.

Maximum improvement in growth of oilseed rape was reported when intercropped with Phaseolus vulgaris in 3:1 row arrangement as compared to the sole crop (Khola, 1988). Shoot height, dry matter per plant and Leaf Area Index (LAl) of toria (Brassica rapa var. toria) increased when intercropped with oilseed rape (Brassica napus) as compared to sole toria. The maximum increase was recorded in 1:1 crop geometry. Toria intercropping reduced the growth parameters in Brassica napus than its sole cultivation.

Mankotia et al. (1994) reported that growth of gobhi sarson sown at 45 or $60 \mathrm{~cm}$ was not affected by intercropping with pea in 1:1 row ratio. Pawar et al. (2019) reported that plant height of GSC 7 cultivar of oilseed rape in oilseed rape + garden pea system was highest in 1:2 row ratio (90 cm apart) and was statistically at par with GSC $7+$ garden pea in 1:1 row ratio (60 cm apart) as compared to GSC 6 and Hyola PAC 401 based intercropping systems.

An experiment was conducted by Shoaib et al. (2014) to improve forage yield of winter nonlegume mixtures in which oats was intercropped with canola under seeding ratios of $3: 1,1: 1$ and $1: 3$. They recommended that for higher dry matter yield of good quality oats, it must be seeded at $1: 1$ row ratio.

Therefore, it can be said that different crops affected the growth of oilseed rape in intercropping systems differently and behavior of oilseed rape cultivars also differs.

Yield attributes and yield: Canola oilseed rape + one row of wheat produced the highest canola oilseed rape seed yield (1.22 t/ha) among intercropping treatments viz., one row of canola oilseed rape after every one, two or three rows of wheat (Ali et al., 2000). A field investigation was conducted by Khan et al. (2009) at Sabour to determine the viability of wheat + canola intercropping systems. Among the different row ratios tested viz., 1:2, 2:3 and 3:2, wheat and rapeseed in 3:2 row proportion resulted in higher yield as compared to their sole crops. In a similar study conducted at Jorhat, Das et al. (1992) studied the feasibility of intercropping of wheat variety Sonalika with rapeseed (M 27) and mustard (Pusa Bold and Varuna) varieties in four row proportions i.e. 1:1, 2:1, 3:1 and 4:1. Sonalika and $M 27$ in 1:1 row proportions produced highest yield, BCR and monetary returns. An experiment was conducted to determine the feasibility of wheat-canola intercropping systems by Naeem et al. (2013) under two spatial patterns viz., (row and mixed intercropping) and found that four wheat rows alternating with four canola rows resulted in highest crop productivity. In contrary to this, intercropping of wheat and oilseed rape in 8:3 and 12:4 row proportions resulted in highest values of yield attributes leading to increased grain yield (Mardfar et al., 2013).

Gupta and Saini (1986) reported that simultaneous sowing of Indian rape and oilseed rape in alternate rows at $22.5 \mathrm{~cm}$ row spacing resulted in 58 and 99 per cent higher oilseed rape equivalent seed yield than sole crop of oilseed rape and Indian rape, respectively. In a field investigation at Kangra, Chaudhary and Singh (1993) studied intercropping systems of gobhi sarson (variety Bhawani) and toria (variety HPN 1) and found that gobhi sarson and toria in alternate rows at 22.5 cm spacing gave higher productivity.

At Ludhiana, Punjab, Kaur et al. (2017) evaluated the performance of canola oilseed rape in intercropping systems. Seed yield of non canola oilseed rape (1.85 t/ha) when intercropped with 
Indian rape $(1: 1,22.5 \mathrm{~cm})$ was $45.7 \%$ lower than its sole crop yield. But, oilseed rape equivalent yield produced by non-canola oilseed rape + Indian rape $(1: 1,22.5 \mathrm{~cm})$ was $22.9 \%$ higher than sole non canola oilseed rape. Oilseed rape equivalent yield in canola oilseed rape + Indian rape sown in $1: 1$ and $2: 1$ row proportions at $22.5 \mathrm{~cm}$ row spacing was 16.9 and $20.1 \%$ higher than sole canola oilseed rape (1.63 t/ha).

Intercropping of oilseed rape with $P$. vulgaris resulted in improvement in various yield attributes viz., branches per plant, siliquae per plant and seed yield per plant of oilseed rape as compared to the sole crop whereas yield attributes of oilseed rape decreased when intercropped with toria as compared to sole crop. The performance of component crops was better in 3:1 row arrangement (Khola, 1988).

Simultaneous sowing of oilseed rape at $45 \mathrm{~cm}$ row -row spacing and cross sowing of oats at $25 \mathrm{~cm}$ resulted in higher seed yield of oilseed rape (1.32 $\mathrm{t} / \mathrm{ha})$ followed by oilseed rape $(0.78 \mathrm{t} / \mathrm{ha})$ sown at $90 \mathrm{~cm}+2$ rows of oats and barley at $22.5 \mathrm{~cm}$ row spacing (Jamwal, 2002).

A study was conducted by Zabih and Saeedlpour (2015) to evaluate the competitive effects of different densities of rapeseed and broad bean intercropping on rapeseed yield. Planting of broad bean and rapeseed was done as sole crops and also in the different row proportions like 3:1, 2:2 and $1: 3$ with 20 bushes $/ \mathrm{m}^{2}$. Increase in number of siliquae per plant, number of seeds per siliqua, thousand seed weight as well as seed yield was seen due to increase in the density of rapeseed. Significant negative correlation was observed between rapeseed yield components and broad bean density. It was observed that higher density of broad bean (about $25 \%$ ) can cause severe rapeseed yield reduction.

Intercropping of gobhi sarson (oilseed rape) with potato increased the branches per plant, siliquae per plant, seed per siliqua and yield per plant of gobhi sarson by 76, 108, 39 and 76 per cent, respectively as compared to its sole crop at Hisar. Intercropping of gobhi sarson with potato decreased the seed yield of gobhi sarson by only 21.9 per cent compared to sole crop in spite of plant population of only one-fourth of its sole crop. Relay intercropping of Egyptian clover, onion and wheat with gobhi sarson after harvesting potato did not adversely influence the yield and yield attributes of gobhi sarson as compared to the fallow field left after the harvesting of potato crop (Narwal and Kadian, 1991). At New Delhi, seed yield of Brassica napus was 52.1 per cent in the intercropping with potato in 3:1 replacement series compared to the sole crop yield (Rana and Gangasaran, 1999).

Intercropping of different oilseed rape cultivars (GSC 6, GSC 7 and Hyola PAC 401) with garden pea in either $1: 1(60 \mathrm{~cm})$ or $1: 2$ row ratios $(90 \mathrm{~cm})$, produced significantly higher oilseed rape equivalent yield than their respective sole crops (Pawar et al., 2019). Mankotia et al. (1994) found that intercropping of gobhi sarson (sown at 45 or $60 \mathrm{~cm}$ ) and peas in rows or by broadcasting method gave higher yield than sole gobhi sarson. Intercropping of pea in 1:1 row ratio with gobhi sarson sown at $45 \mathrm{~cm}$ row spacing produced significantly higher yields of gobhi sarson (1.72 t/ha) and pea (0.89 t/ ha) and gobhi sarson equivalent yield (2.42 t/ha).

Different oilseed rape cultivars when intercropped with different crops viz., cereals, legumes, vegetables or other oilseed crops prove to be more productive and economically beneficial over their monoculture at different row proportions or spacings. The appropriate or suitable row ratio combinations vary from one place to another place and varies with crop cultivars (Singh et al., 2010).

Competitive indices: Among different oilseed rape based intercropping treatments, Kaur et al. (2017) obtained the highest equivalent yield of $2.27 \mathrm{t} \mathrm{ha}^{-1}$ and LER of 1.41 from oilseed rape + Indian rape at $22.5 \mathrm{~cm}$ (2:1). Another experiment was conducted by Aslani and Saeedipour (2015) to evaluate the competitive effects of different densities of wild mustard and rapeseed planted in different ratios of 2:6, 4:4, 6:2, 8:0 and 0:8 plants per pot using replacement series. Results indicated that competition coefficient of rapeseed as against wild mustard was greater in 6:2 row ratio treatment. Competition indices revealed that rapeseed was less benefitted from more competitive ability than wild mustard.

In wheat + canola intercropping system, pattern of four alternating rows of wheat and canola gave higher LER of 1.37 (Naeem et al. 2013). Khan et al. (2012) also studied different wheat-canola intercropping systems and found that wheat + hybrid canola (4:2) row ratio recorded the maximum LER. Ali et al (2000) obtained higher LER of 1.17 from wheat + canola in 1:1 row ratio as compared to $2: 1$ and 3:1 row ratios. At Jorhat, Das et al. (1992) studied the feasibility of intercropping of wheat variety Sonalika with rapeseed and mustard varieties in four row proportions i.e. 1:1, 2:1, 3:1 and 4:1 and reported that wheat and rapeseed (M 27) in $1: 1$ row proportions produced highest LER value. At Ludhiana, Singh et al. (2014) conducted studies on oilseed rape +oat systems and found that intercropping of one to three rows of oat for fodder purpose in between two rows of non canola or canola gobhi sarson planted at different row spacings viz., $45,60,75$ or $90 \mathrm{~cm}$, resulted in higher LER values (1.26 to 1.45) in comparison to sole gobhi sarson. Pawar et al. (2019) studied oilseed rape +garden pea intercropping systems and reported significantly higher values of aggressivity from flat sown oilseed rape cultivars viz., GSC 6 (2.68), GSC 7 (2.74) and Hyola PAC 401(2.74) intercropped with 
garden pea in $1: 2$ row ratio $(90 \mathrm{~cm})$. Oilseed rape was the dominant species over the garden pea. LER values of different oilseed rape based intercropping systems were more than one, indicating yield advantage from all the intercropping systems as compared with sole oilseed rape.

Competitive indices of oilseed based intercropping system varies with crops, cultivars as well with different locations.

Economics: At Kangra, Chaudhary and Singh (1993) studied various intercropping systems of gobhi sarson and toria and found that gobhi sarson and toria in 1:1 row ratio at $22.5 \mathrm{~cm}$ spacing was more remunerative among them. Kaur et al. (2017) also found that oilseed rape based intercropping system resulted in higher net returns over sole crops. Maximum net returns of ₹ 49,100 /ha was obtained from oilseed rape + Indian rape planted at $22.5 \mathrm{~cm}$ in 2:1 row ratio. In wheat + rapeseed system, Khan et al. (2009) obtained higher returns of about 34942 ₹/ha when wheat and rapeseed were sown in 3:2 row proportions as compared to their sole crops, in which substantial increase in economic returns was to the tune of 11786 ₹/ha (51 per cent) and 15302 ₹/ ha (78 per cent) in wheat and rapeseed, respectively. Ali et al (2000) recorded higher net income (22487 ₹/ha) and B: C (2.46) from wheat + canola in $1: 1$ row ratio. Khan et al. (2012) studied different wheat + canola intercropping systems (3:1, $4: 2,3: 1,4: 2$ row ratios) and found that wheat + hybrid canola in 4:2 row ratio resulted in maximum net income, benefit cost ratio (BCR) and marginal rate of return. Naeem et al. (2013) observed that for higher net returns (107492 ₹/ha) and BCR (2.76), farmers should cultivate wheat + canola in the pattern of four rows of wheat along with four rows of canola. In a field investigation conducted at Jorhat, Das et al. (1992) studied the feasibility of intercropping of wheat variety Sonalika with rapeseed (M 27) and mustard (Pusa Bold and Varuna) varieties in four row proportions i.e. 1:1, $2: 1,3: 1$ and 4:1. Wheat (Sonalika) and rapeseed (M 27) in 1:1 row proportion produced highest yield, BCR and monetary returns.

In an investigation conducted at Ludhiana, Singh et al. (2014) found that intercropping of 1, 1, 2, 2, 2 and 3 rows of oats fodder in between two rows of GSL 1 variety of gobhi sarson planted at 45,60 , $60,75,90$ and 90 row spacing produced significantly higher net returns which were ₹ 54555, 54397, 57540, 55206, 52333 and 57637/ha, respectively as compared to sole gobhi sarson crop (₹ 44,834/ha). Significantly higher net returns were also obtained in gobhi sarson variety GSC 6 and the corresponding values were ₹ 53621 , $52074,56394,52832,52794,56556$ /ha as compared to sole canola gobhi sarson ( $₹ 41520 / \mathrm{ha}$ ). At Jammu, Jamwal (2002) reported that gobhi sarson (variety GSL 1) planted at $45 \mathrm{~cm}$ row-row spacing+ cross sowing of oats at $25 \mathrm{~cm}$ row spacing recorded higher mean net returns (₹14553/ha) as compared to other intercropping systems.

Pawar et al. (2019) evaluated different oilseed rape based cropping systems at Ludhiana, comprising of three cultivars of oilseed rape sown in combination with garden peas in different row ratios viz., 1:1 $(60 \mathrm{~cm})$ or 1:2 $(90 \mathrm{~cm})$ under different planting methods. There was increase in net returns from the different oilseed rape based intercropping systems as compared with their respective sole crops and the increase was to the tune of 5300 to 7600,4200 to 6500 and 9100 to 11000 ₹/ha in GSC 6, GSC 7 and Hyola PAC 401, respectively.

Intercropping of oilseed rape undertaken in different row proportions with different crops resulted in higher net returns as compared to sole crops.

\section{Conclusion}

The review of above mentioned studies indicated that intercropping of oilseed rape gave higher system productivity and profitability as compared to the sole crops. Inclusion of component crops i.e., wheat, legumes, fodders and other oilseeds in different row proportions resulted in higher yield advantage and efficient resource utilization in terms of higher equivalent yields and LER. The appropriate planting pattern involving row ratio combination and spacing also varies with oilseed rape cultivars and from place to place.

\section{REFERENCES}

1. Ali. Z., Malik, M. A. and Cheema, M. A. (2000). Studies on determining a suitable canola-wheat intercropping pattern. Int. J. Agric. Bio., 2: 42-44.

2. Anonymous (2020). Area and production of rapeseed and mustard in India. http// www.indiastat.com.

3. Aslani, S. and Saeedipour, S. (2015). Competitive interaction of canola (Brassica napus) against wild mustard (Sinapis arvensis) using replacement series method. Walia J., 31: 111-16.

4. Aziz, M., Mahmood, A., Asif, M. and Ali, A. (2015). Wheat- based intercropping. J Animal Plant Sci., 25: 896 -907 .

5. Chaudhary, J. B. and Singh, C. M. (1993). Effect of intercropping gobhi sarson (Brassica napus L.) and toria (Brassica napus var napus) on their land equivalent ratio and net return. Indian J. Agric. Sci., 63: 825-26.

6. Das, K., Shyam, N. N. and Baroova, S. R. (1992). Intercropping of wheat (Triticum aestivum) with rapeseed (Brassica napus) and mustard (Brassica juncea) under rainfed conditions. Indian J. Agron., 37: 543-45.

7. Diepenbrock, W. (2000). Yield analysis of winter oilseed rape (Brassica napus L.). Field Crops Res., 67: 35-49. https://doi.org/10.1016/S0378-4290(00)00082-4.

8. Gupta, T. R. and Saini, J. S. (1986). Follow relay cropping of toria and gobhi sarson - A diversification in cropping pattern. Seeds and Farms, 58(1): 35-36.

9. Jamwal, J. S. (2002). Planting pattern in gobhi sarson (Brassica napus) and winter fodder intercropping under rainfed conditions of Jammu. Indian J. Agron., 47: 51417. 


\section{Kaur, J. / J. Appl. \& Nat. Sci. 12(1): 66 - 70 (2020)}

10.Kaur, M., Sardana, V. and Sharma, P. (2017). Performance of canola oilseed rape (Brassica napus), Ethiopian mustard (Brassica carinata) and Indian rape (Brassica rapa) in intercropping system. Indian J Agron., 62: 211-14.

11.Khan, M. B., Khan, M., Hussain, M., Farooq, M., Jabran, K. and Lee, D. J. (2012). Bio-economic assessment of different wheat-canola intercropping systems. Int. J. Agric. Biol., 5: 769-74. DOI: 12-108/AKA/2012/14-5769-774.

12.Khan, U. R., Rashid, A. and Khan, M. S. (2009). Seed yield and monetary return of wheat crop as affected by intercropping with canola (Brassica napus L.). J. Agric. Res., 47:165-70.

13.Khola, O. P. S. (1988). Intercropping studies of Brassica campestris var. toria and Phaseolus vulgaris $L$. in oilseeds Brassicas. M Sc thesis, Chaudhary Charan Singh Haryana Agricultural University, Hisar, Haryana.

14.Kumar, A. (2014). Challenge of edible oils: Can Brassicas deliver? Presidential address delivered in the second National Brassica Conference on 'Brassicas for addressing edible oil and nutritional security' organized by Society for Rapeseed Mustard Research at Punjab Agricultural University, Ludhiana. February 14-16.

15.Mankotia, B.S., Negi, P.S. and Singh, B. (1994). Influence of pea (Pisum sativum L.) intercropping and fertility levels on gobhi sarson (Brassica napus L.) in mid-hill conditions of Himachal Pardesh. Himachal J. Agric. Res. 20: 5-11.

16.Mardfar, R. A., Raei, Y., Nassab, A. D. M., Khaghaninia, S. and Amini, R. (2013). Yield and yield components of wheat as influenced by intercropping of oilseed rape and fertilizers. J. Bio. Env. Sci. 3: 38-46.

17.Naeem, M., Cheema, Z. A., Ahmad, A. H., Wahid, A., Farooq, O. and Rehman, H. S. (2013). Agro- economic assessment of wheat (Triticum aestivum) canola (Brassica napus) intercropping systems under different spatial patterns. Int. J. Agric. Biol., 15: 1325-30. DOI: 13S-024/2013/15-6-1325-1330.

18.Narwal, S. S. and Kadian, H. S. (1991). Effect of potato (Solanum tuberosum) intercropping and cutting management on yield of gobhi sarson (Brassica napus subsp. oleifera var. annua) and relay crops. Indian J. Agric. Sci. 61: $45-48$

19.Narwal, S. S. and Parkash, V. (1989). Influence of gobhi sarson (Brassica napus) and Indian mustard (Brassica juncea) intercropping on potato (Solanum tuberosum) yield, land equivalent ratio and net returns. Indian $\mathrm{J}$. Agric. Sci. 59: 786-90.

20.Narwal, S. S. and Parkash, V. (1992). Comparative performance of gobhi sarson (Brassica napus subsp. oleifera var. annua) and Indian mustard (Brassica juncea) in intercropping with potato (Solanum tubrosum). Indian J. Agric. Sci. 62: 35-40.

21.Pawar, S., Kaur, J. and Singh, T. (2019). Productivity and economics of oilseed rape based intercropping systems. Agric. Res. J. 56 (2): 242-247. DOI: 10.5958/2395146X.2019.00038.3

22.Rafey, A. and Prasad, N. K. (1991). Biological potential and economic feasibility of intercropping oilseeds and pulses with safflower (Carthamus tinctorius) in drylands. Indian J. Agric. Sci., 61: 893-97.

23.Rana, D. S. and Gangasaran (1999). Comparative performance of oleiferous Brassica species in intercropping with potato (Solanum tuberosum L.) staggered sowing and fertility levels. Indian J. Agron., 44: 281-88.

24.Rathi, K. S. and Keim, D. C. (1982) Raise mustard from potato fields. Indian Fmg., 32(1): 21-23.

25.Reddy, B. N. and Suresh. G. (2008). Crop diversification with oilseeds for higher productivity. Souvenir paper presented at the National symposium on 'New Paradigms in Agronomic Research'. pp 33-37. Navsari Agricultural University, Navsari, Gujarat. November 19-21.

26.Shoaib, M., Ayub, M., Shehzad, M., Akhtar, N., Tahir, M. and Ari, M. (2014). Dry matter yield and forage quality of oat, barley and canola mixture. Pak. J. Agri. Sci., 52: 433 -39 .

27.Singh, C. (2013). Effect of row spacing and planting pattern on the productivity of gobhi sarson (Brassica napus var. napus) and oats fodder (Avena sativa L.) intercropping system. M Sc. Thesis, Punjab Agricultural University, Ludhiana, India.

28.Singh, C., Singh, T., Singh, A. and Kang, J. S. (2014). Productivity of gobhi sarson (Brassica napus var. napus) and oats fodder (Avena sativa L.) intercropping system in relation to planting patterns and row spacing. Indian $\mathrm{J}$. Ecol., 41: 116-20.

29.Singh, R. A. and Rathi, K. S. (1984). Economics of potato and potato + mustard cultivation under different rates of nitrogen. Indian J. Agron. 30: 555-56.

30.Singh, R. K., Kumar, H. and Singh, A. K. (2010). Brassica based intercropping systems-a review. Agric. Rev. 31: 253-66.

31.Uzun, B., Yol, E. and Furat, S. (2012). The influence of row and intra-row spacing to seed yield and its components of winter sowing canola in the true Mediterranean type environment. Bulgarian J. Agric. Sci., 18: 83-91.

32.Zabih, V. and Saeedlpour, S. (2015). Effect of different planting pattern of (Rapeseed-Broad bean) using replacement series method on yield performance of rapeseed and weed biomass. J. Agron., 14: 286- 91. DOI: 10.3923/ja.2015.286.291. 